\title{
ASPEK HUKUM FINTECH SYARIAH UNTUK PENINGKATAN FINDRISING WAKAF UANG DI INDONESIA
}

\author{
Siska Lis Sulistiani \\ Universitas Islam Bandung \\ siska.sulistiani@unisba.ac.id
}

Abstract: This study aims to determine the legal aspects of financial technology related to endowments in making finding money endowments in indonesia. Waqf money in indonesia is very potential, if maximized by all aspects including legal instruments and technological advances in socializing the urgency and benefits of waqf for the economic, social and religious progress of the community. The method used is a normative juridical method through primary, secondary and tertiary legal data relating to fintech and endowments of money. The findings of this study are that the development of legal related to waqf fintech can be done from both national law and islamic law in finding endowments for benefit as long as they maintain harmony and waqf requirements, and maintain the core of waqf assets collected to be developed in other more useful forms.

Keywords: fintech, money waqf, findrising, law

Abstrak: Penelitian ini bertujuan untuk mengetahui aspek hukum financial technologi terkait wakaf dalam memidahkan findrising wakaf uang di Indonesia. Wakaf uang di Indonesia sangat potensial, apabila dimaksimalkan segala aspeknya termasuk perangkat hukum dan kemajuan teknologi dalam mensosialisasikan urgensi dan manfaat wakaf untuk kemajuan ekonomi , sosial dan keagamaan masyarakat. Metode yang digunakan adalah metode yuridis normative melalui data hukum primer, sekunder dan tersier yang berkaitan dengan fintech dan wakaf uang. Temuan dari penelitian ini bahwa 
pengembangan hukum terkait fintech wakaf dapat dilakukan baik dari hukum nasional maupun hukum islam terkait findrising wakaf untuk kemaslahatan selama terpelihara aspek rukun dan syarat wakaf, serta terjaga inti dari asset wakaf yang dihimpun untuk dapat dikembangkan dalam bentuk lain yang lebih bermanfaat.

Kata kunci: fintech, wakaf uang, findrising, hukum

\section{PENDAHULUAN}

Wakaf uang yang dikenal dengan istilah wakaf tunai merupakan bagian dari instrument filantropi Islam yang lebih fleksibel dan multimanfaat dibanding zakat. Berdasarkan Undang-undang wakaf no.41 tahun 2004 disebutkan bahwa asset wakaf dari sisi bentuknya dapat berupa benda bergerak dan benda tidak bergerak. Untuk benda yang tidak bergerak wakaf uang menjadi salah satu pilihannya selain wakaf surat berharga.

Aspek hukum merupakan fondasi awal dalam pembentukan inovasi wakaf, dikarenakan fondasi yang jelas akan menjadikan segala bentuk trobosan baru dalam pengembangan wakaf sesuai pijakan dan lebih terjaga sebagaimana tujuan awal dari wakaf itu sendiri, yaitu menahan inti dari asset wakaf dan mengembangkan manfaatnya. Findrising wakaf uang di Indonesia berdasarkan UU wakaf No.41 tahun 2004 harus melalui perbankan syariah atau disebut dengan LKS-PWU (lembaga keuangan syariah penerima wakaf uang) yang ditunjuk resmi oleh kementrian agama serta berkordinasi dengan badan wakaf Indonesia sebagai lembaga resmi yang menangani masalah pengelolaan wakaf di Indonesia. Sehingga tidak semua lembaga keuangan syariah di Indonesia berwenang dalam upaya findrising wakaf uang, sampai tahun 2019 baru ada 18 LKS-PWU yang terdaftar resmi dalam findrising wakaf uang di Indonesia, diantaranya: Bank Muamalat Indonesia, Bank Syariah Mandiri, Bank BNI Syariah, Bank Mega Syariah, Bank DKI Syariah, Bank BTN Syariah, Bank Syariah Bukopin, BPD Jogja Syariah, BPD Kalbar Syariah, BPD Jateng Syariah, BPD Kepri Riau Syariah, BPD Jatim Syariah, BPD 
Sumut Syariah, Bank CIMB Niaga Syariah, Bank Panin Dubai Syariah, BPD Sumsel \& Babel Syariah, Bank BJB Syariah dan BPD Kaltim \& Kaltara Unit Usaha Syariah (BWI, 2019).

Perbankan syariah dipilih karena memiliki beberapa keunggulan salah satunya adalah dari keberadaannya sebagai institusi keuangan yang telah kompetibel dengan kemajuan teknologi, serta pertimbangan akuntabilitas menjadi salah satu alasan LKS-PWU terlibat sebagai lembaga yang menjadi penentu kesuksesan findrising wakaf uang di Indonesia.

Potensi ekonomi digital di Indonesia sangat besar dan penting untuk dikembangkan. Kecepatan laju inovasi mengakibatkan berbagai perubahan dalam segala aspek kehidupan dalam hal ini bidang keuangan termasuk sistem pembayaran dimana perubahan tersebut semakin singkat yang berdampak pada semakin sempit response time otoritas untuk membuat kebijakan. FinTech secara global menggambarkan secara pesat bahwa FinTech berkembang di berbagai sektor, mulai dari startup pembayaran, peminjaman (lending), perencanaan keuangan (personal finance), investasi ritel, pembiayaan (crowdfunding), remitansi, riset keuangan, dan lain-lain (Ridwan Muchlis, 2018, 340).

Indonesia juga memiliki modal besar untuk mendukung perkembangan fintech yaitu jumlah masyarakat kelas menengah yang mencapai 45 juta orang, serta total pengguna internet yang mencapai 150 juta (cnbcindonesia, 2019). Menurut IOSCOTeknologi Finansial adalah bisnis yang berfokus pada penyedia gagasan jasa finansial yang menggunakan perangkat lunak dan modern. Sedangkan menurut Wonglimpiyarat Fintech telah mendapat perhatian secara global sebagai teknologi menantang yang akan memberdayakan perusahaan untuk bersaing dengan efektif pada abad dua puluh satu saat ini. Pemerintah didunia saat ini telah memberikan perhatian mengenai tantangan dan merancang kebijakan serta peraturan untuk mendukung perkembangan fintech( Yarli, 2018). 
Financial technology merupakan bagian dari sarana kemajuan teknologi yang dapat disinergikan dengan findrising wakaf mengingat di era milenial ini, sebagian besar transaksi finansial digunakan melalui proses berbasis internet. Kemudahan yang ditawarkan dalam financial technology menjadi daya Tarik tersendiri untuk memudahkan semua pihak khususnya dalam penghimpunan dana dalam program wakaf uang di Indonesia.

\section{METODE}

Metode Penelitian yang digunakan adalah metode penelitian kualitatif yang menjadikan metode yuridis normative sebagai bentuk pendekatannya. Sehingga data yang digunakan adalah data sekunder yang terdiri atas data hukum primer yang terdiri dari peraturan perundang-undangan, dalil-dalil hukum yang bersumber dari al-qur'an dan hadis. Data hukum sekunder yang digunakan adalah tesis disertasi terkait fintech dan wakaf, jurnal dan artikel ilmiah terkait. Metode pengumpulan data yang digunakan adalah metode studi pustaka dan kemudian dianalisis dengan menggunakan metode deskriptif analisis, serta dilihat aspek sinkronisasi hukum terkait wakaf uang dan financial technologi di Indonesia.

\section{KERANGKA TEORI}

Kata wakaf atau waqf ( الوقف) berasal dari bahasa Arab yang berasal dari akar kata wa-qa-fa ( وقف ) berarti menahan, berhenti, diam di tempat atau berdiri. Kata waqafa-yaqifu-waqfan semakna dengan kata habasa-yahbisu-tahbisan ( maknanya terhalang untuk menggunakan. Kata waqf dalam bahasa Arab mengandung makna menahan, menahan harta untuk diwakafkan, tidak dipindah milikkan (Al-Mishri, 1301).

Menurut istilah meskipun terdapat perbedaan penafsiran, disepakati bahwa makna wakaf adalah menahan dzatnya benda dan memanfaatkan hasilnya atau menahan dzatnya dan menyedekahkan manfaatnya (Zahrah, 1971). Adapun 
perbedaan pendapat para ulama fiqh dalam mendefinisikan wakaf diakibatkan cara penafsiran dalam memandang hakikat wakaf.

Wakaf uang adalah wakaf berupa uang tunai yang diinvestasikan ke dalam sektor-sektor ekonomi yang menguntungkan dengan ketentuan presentase tertentu digunakan untuk pelayanan sosial (Bakar: 2006). Dalam konteks keindonesiaan wakaf uang adalah wakaf berupa uang dalam bentuk rupiah yang dikelola secara produktif, hasilnya dimanfaatkan untuk mawquf alaih.

Sedangkan, istilah lain yang berkembang dan dikenal yaitu wakaf melalui uang, yaitu wakaf dengan memberikan uang untuk dibelikan/dijadikan harta benda tidak bergerak atauharta benda bergerak sesuai yang dikehendaki wakif atau program/proyek yang ditawarkan kepada wakif, baik untuk keperluan sosial maupun produktif/investasi (Syarjaya dan Fahruroji: 2017).

Istilah lain wakaf uang dikenal juga dengan istilah wakaf tunai (cash waqf atau waqf al-nuqud), menurut UU No.41 tahun 204 tentang wakaf merupakan salah satu wakaf benda bergerak yang dispesifikasi berupa uang. Selain itu, berdasarkan fatwa MUI tentang wakaf uang dapat dilakukan seseorang, kelompok orang, lembaga atau badan hukum dalam bentuk uang tunai, termasuk dalam pengertian uang adalah surat berharga.

Sehingga wakaf uang menjadi bagian dari wakaf produktif dengan mekanisme investasi dana wakaf dan menyalurkan hasil dari pokok modal yang diinvestasikan. Membandingkannya dengan wakaf tanah misalnya, wakaf tanah hanya dinikmati oleh masyarakat yang berdomisili di sekitar harta wakaf tersebut berada. Sementara, masyarakat miskin berdomisili di berbagai tempat, sehingga dibutuhkan sumber pendanaan baru yang tidak terikat tempat dan waktu. Sebab uang bersifat fleksibel dan tidak mengenal batas wilayah pendistribusian. Perbedaan wakaf uang dan wakaf melalui uang adalah sebagai berikut (Syarjaya dan Fahruroji: 2017):

a. Wakaf Uang 
1) Wakaf uang hanya untuk tujuan produktif atau investasi baik di sector ril maupun sector keuangan.

2) Investasi wakaf uang tidak terikat pada satu jenis investasi tetapi terbuka untuk semua jenis investasi yang aman, menguntungkan, dan sesuai syariah serta peraturan perundang-undangan.

3) Dalam wakaf uang, yang diberikan kepada penerima manfaat wakaf (mawquf alaih) adalah keuntungan atau hasil investasi bukan uang wakafnya.

4) Dalam wakaf uang, harta benda wakafnya adalah uang yang harus dijaga nilai pokoknya dengan menginvestasikan pada property atau produksi barang maka boleh dijual karena bukan sebagai harta benda wakaf.

b. Adapun wakaf melalui uang, adalah sebagai berikut:

1) Wakaf melalui uang dapat ditujukan untuk keperluan social atau produktif / investasi

2) Investasi wakaf melalui uang terikat dengan satu jenis investasi yang dikehendaki wakafi atau program/proyek wakaf yang ditawarkan kepada wakif. Demikian juga dengan wakaf melalui uang untuk tujuan social yang terikat peruntukannya sesuai kehendak wakif atau program/proyek wakaf yang ditawarkan kepada wakif.

3) Wakaf melalui uang yang diproduktifkan atau diinvestasikan maka keuntungan dari investasi itu yang diberikan kepada mawquf alaih, sedangkan wakaf melalui uang untuk keperluan social maka uangnya yang langsung dimanfaatkan.

4) Dalam wakaf melalui uang, harta benda wakafnya adalah barang/ benda yang dibeli atau diwujudkan dengan uang yang harus dijaga, dilindungi, tidak boleh dijual, diwariskan dan dihibahkan.

5) Bagi lembaga wakaf, wakaf uang harus dijadikan sebagai peluang untuk mengembangkan berbagai layanan social dan / atau bisnis 
berbasis wakaf, sedangkan bagi masyarakat terbuka kesempatan menjadi wakif dengan nominal uang berapapun sehingga siapapun bisa memperoleh pahala wakaf yang terus mengalir.

Dari perbedaan antara wakaf uang dan wakaf melalui uang tersebut, digambarkan dalam skema berikut:
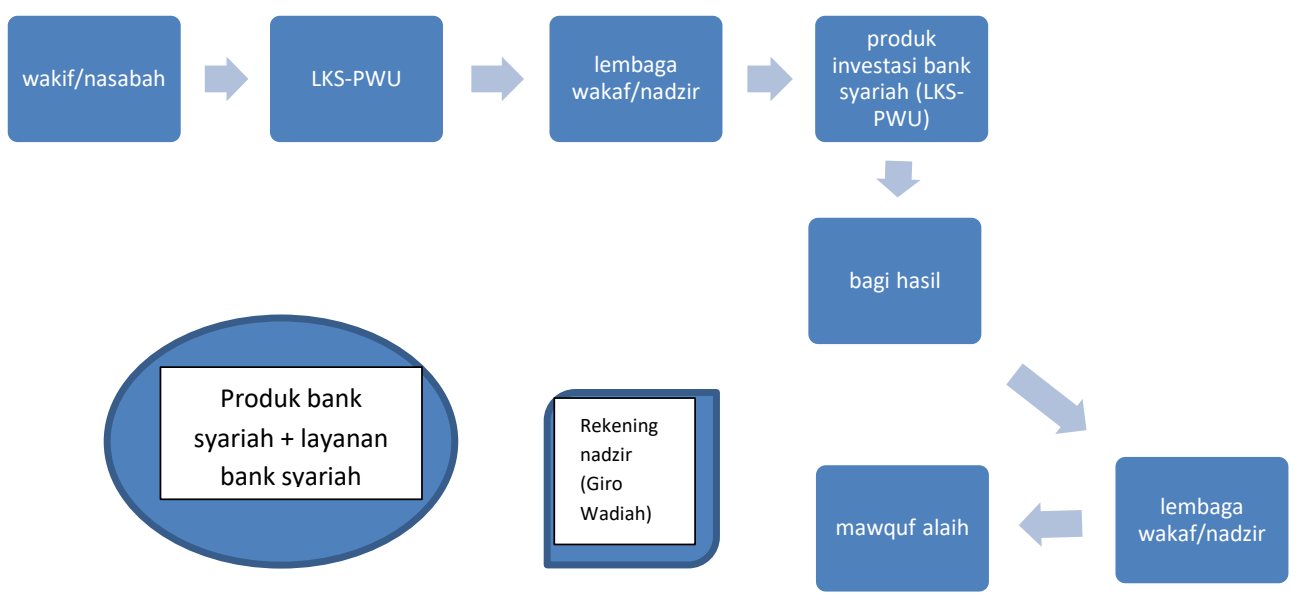

Gambar 2

Skema wakaf uang (Syarjaya dan Fahruroji: 2017). 

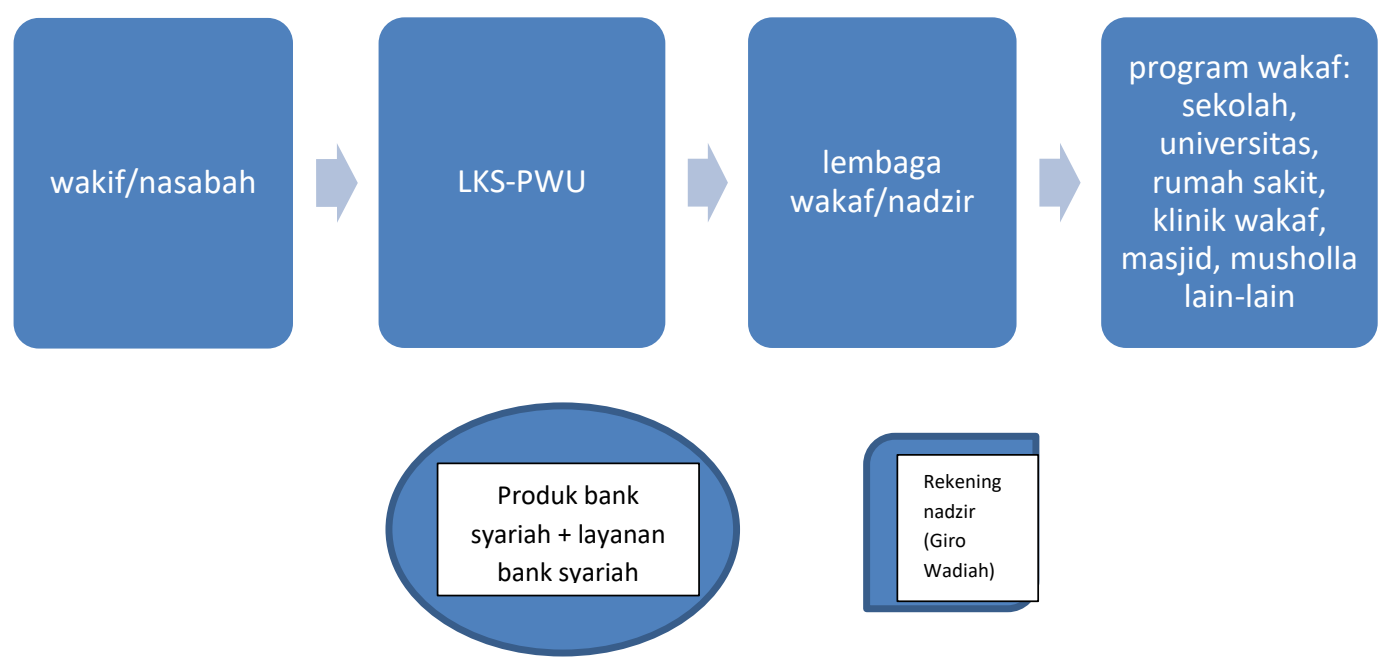

Skema wakaf melalui uang (Syarjaya dan Fahruroji: 2017).

Dibandingkan dengan wakaf tanah, wakaf uang belum banyak dikenal dan dipraktikan di Indonesia. Diantara dasar hukumnya adalah Qs. Al-Imran :92, tentang perintah agar manusia menyedekahkan sebagian harta yang dicintainya.

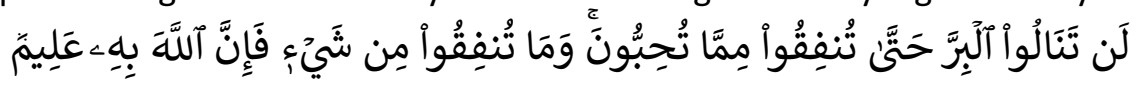

"Kamu sekali-kali tidak sampai kepada kebajikan (yang sempurna), sebelum kamu menafkahkan sehahagian harta yang kamu cintai. Dan apa saja yang kamu nafkahkan maka sesungguhnya Allah mengetahuinya".

Adapun ayat lain berbicara tentang tentang balasan yang berlipat ganda bagi orang yang menyedekahkan hartanya di jalan Allah dengan ikhlas dan pelakunya dijamin akan terhindar dari rasa khawatir (takut) dan sedih seperti QS. Al-Baqarah: 261-261, 


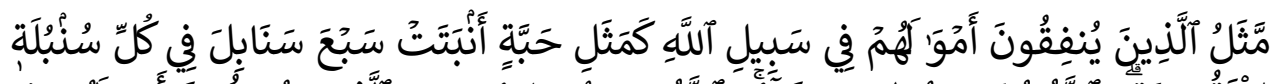

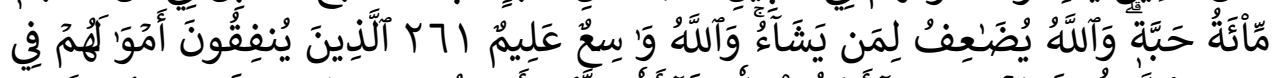

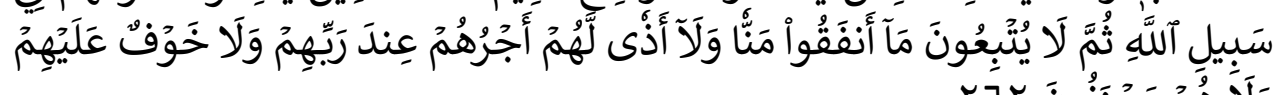

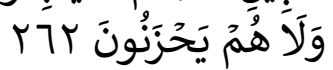

"Perumpamaan (nafkah yang dikeluarkan oleh) orang-orang yang menafkahkan hartanya di jalan Allah adalah serupa dengan sebutir benih yang menumbuhkan tujuh bulir, pada tiap-tiap bulir seratus biji. Allah melipat gandakan (ganjaran) bagi siapa yang Dia kehendaki. Dan Allah Maha Luas (karunia-Nya) lagi Maha Mengetahui, Orang-orang yang menafkahkan hartanya di jalan Allah, kemudian mereka tidak mengiringi apa yang dinafkahkannya itu dengan menyebut-nyebut pemberiannya dan dengan tidak menyakiti (perasaan si penerima), mereka memperoleh pahala di sisi Tuhan mereka. Tidak ada kekhawatiran terhadap mereka dan tidak (pula) mereka bersedih hati. "

Tidak hanya ayat Alqur'an, mayoritas ulama menyatakan asal mula disyari'atkannya ibadah wakaf dalam Islam adalah pada periode Rasulullah SAW, di mana ketika itu Umar bin Khattab mendapat sebidang tanah di Khaibar (AlUsman: 2008). sebagaimana hadis berikut:

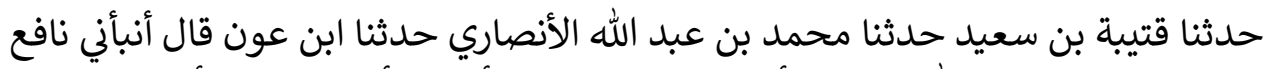

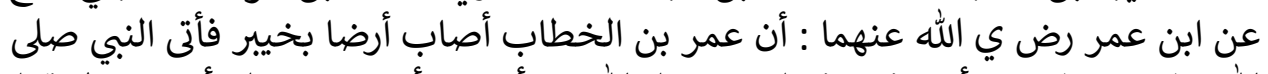

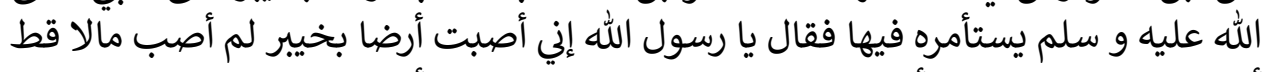

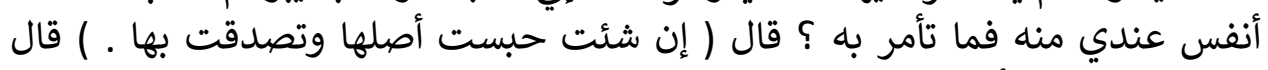

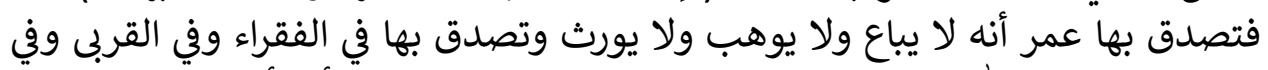

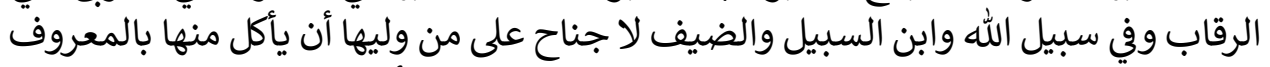

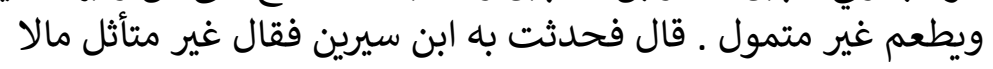
“Dari Ibnu Umur r.a. (dilaporkan) bahwa 'Umar Ibn al-Khattab memperoleh sebidang tanah di Khaibar, lalu beliau datang kepada Nabi Saw untuk minta instruksi beliau tentang tanah tersebut. Katanya: Wahai Rasulullah, saya memperoleh sebidang tanah di Khaibar yang selama ini belum pernah saya 
peroleh harta yang lebih berharga dari saya dari padanya. Apa instruksimu mengenai harta itu? Rasulullah bersabda: Jika engkau mau, eng \kau dapat menahan pokoknya (melembagakan bendanya) dan menyedekahkan manfaatnya. [Ibnu Umar lebih lanjut] melaporkan: Maka Umar menyedekahkan tanah itu dengan ketentuan tidak boleh dijual, dihibahkan atau diwariskan. Ibnu Umar berkata: Umar menyedekahkankannya kepada orang fakir, kaum kerabat, bidak belian, sabilillah, ibn sabil dan tamu. Dan tidak dilarang bagi orang yang menguasai tanah wakaf itu (mengurus) untuk makan dari hasilnya dengan cara baik (sepantasnya) atau makan dengan tidak bermaksud menumpuk harta". [HR Muslim] .

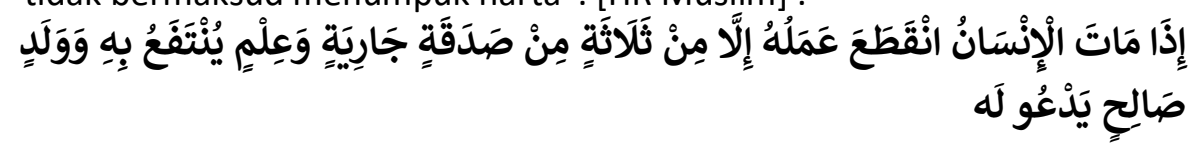

"Dari Abu Hurairah r.a. (dilaporkan bahwa Rasulullah saw bersabda: Apabila seseorang meninggal dunia, maka putuslah amalnya kecuali tiga hal: sedekah yang mengalir, ilmu yang di manfaatkan atau anak salih yang mendo'akannya" [HR. Muslim].

Meskipun wakaf uang telah dipraktikan sejak awal abad kedua hijriah dan telah difatwakan kebolehannya oleh Imam Al-Zuhri, ternyata hukum wakaf uang dalam fikih masih diperdebatkan diantaranya ulama yang memperbolehkan wakaf uang. Madzhab Hanafi membolehkan wakaf uang asalkan hal tersebut telah menjadi 'urf dikalangan masyarakat. Madzhab Hanafi memang berpendapat bahwa hukum yang ditetapkan berdasarkan 'urf mempunyai kekuatan yang sama dengan hukum yang ditetapkan berdasarkan nash (Zuhaili: 1985). Dalil yang digunakan oleh madzhab Hanafi adalah hadis Nabi Saw:

فما رأى المسلمون حسنا فهو عند الله حسن وما رأوا سيئا فهو عند الله سيء "Apa yang dipandang baik menurut kaum muslimin, maka dalam pandangan Allah adalah baik, dan apa yang dipandang buruk oleh kaum muslimin maka dalam pandangan Allah pun buruk. (Hanbal: 2008)" 
Cara mewakafkan uang, menurut kalangan hanafiyah ialah dengan menjadikannnya modal usaha dengan cara mudharabah atau mubada'ah. Adapun keuntungannya disedekahkan kepada yang diberi wakaf (Zuhaili: 1985). Selain itu, Madzhab Maliki berpendapat boleh berwakaf dengan dinar dan dirham (Zuhaili: 1998). Dalam hal ini terdapat penjelasan dalam kitab al-mudawwamah mengenai penggunaan wakaf uang yaitu melalui cara pembentukan dana pinjaman. Kaidahnya ialah uang tersebut diwakafkan dan digunakan sebagai pinjaman kepada pihak tertentu dimana peminjam terikat untuk membayar pinjaman tersebut (Anas: 1994).

Pendapat yang tidak membolehkan wakaf uang, yaitu madzhab Syafi'l berpendapat bahwa harta benda wakaf harus kekal sesuai dengan hadis Rasulullah saw:

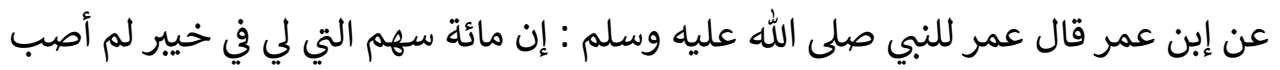
مالا قط أعجب إلي منها قد أردت أن تصدق بها , وقال النبي صلى الله عليه وسلم: أحبس إني أصلها وسبل ثمرتها (رواه النسائي) "Diriwayatkan dari Ibnu Umar, ia berkata: Umar r.a berkata kepada Nabi Saw: "Saya mempunyai seratus saham (tanah, kebun) di Khaibar, belum pernah saya mendapatkan harta yang lebih saya kaguni melebihi tanah itu, saya bermaksud menyedekahkannya. "Nabi Saw berkata "Tahanlah pokoknya dan sedekahkan hasilnya pada sabilillah " (Hr. An-Nasai).

Berdasarkan hadis tersebut, Madzhab Syafi'I berpendapat wakaf dinar dan dirham tidak dibolehkan karena dinar dan dirham akan lenyap dengan dibelanjakan dan sulit mengekalkan zatnya (Al-Ramli: 1984). Namun ulama lainnya yaitu Abu Tsaur membolehkan wakaf dinar dirham dan dia meriwayatkan dari Syafi'I tentang bolehnya mewakafkan uang (dinar dan dirham). Selain itu, ulama yang menolak wakaf uang adalah Imam al-Mawardi dan Madzhab Hanbali. 
Kemudian pada tanggal 11 Mei 2002 Komisi Fatwa Majelis Ulama Indonesia (MUI) menetapkan fatwa tentang wakaf uang, yang isinya adalah sebagai berikut.

a. Wakaf uang (Cash Wakaf/Waqf al-Nuqud) adalah wakaf yang dilakukan seseorang, kelompok orang, lembaga atau badan hukum dalam bentuk uang tunai.

b. Termasuk ke dalam pengertian uang adalah surat-surat berharga.

c. Wakaf uang hukumnya jawaz (boleh).

d. Wakaf uang hanya boleh disalurkan dan digunakan untuk hal-hal yang dibolehkan secara syar'i.

e. Nilai pokok wakaf uang harus dijamin kelestariannya, tidak boleh dijual, dihibahkan, dan atau diwariskan.

Setelah itu, sebagai payung hukum yang mendasari wakaf uang di Indonesia adalah adanya Undang-undang No 41 Tahun 2004 tentang wakaf dan Peraturan Pemerintah Nomor 42 tahun 2006 tentang Pelaksanaan Undang-undang Nomor 41 tahun 2004, yang antara lain mengatur wakaf uang. Selain itu, Peraturan Menteri Agama Nomor 4 Tahun 2009 tentang Administrasi Pendaftaran wakaf uang menyebutkan terkait hal tehnis terkait wakaf uang di Indonesia.

\section{RUKUN SYARAT WAKAF}

Dalam hukum Islam untuk terwujudnya wakaf harus dipenuhi rukun dan syaratnya. Rukun wakaf uang mengacu pada ketentuan wakaf pada umumnya menurut jumhur ulama ada empat, yaitu: wakif, benda yang diwakafkan, mauquf 'alaih (penerima wakaf), ikrar (pernyataan) wakaf. Maka dalam perspektif Kompilasi Hukum Islam untuk adanya wakaf harus dipenuhi 4 (empat) unsur (rukun), yaitu :

1) Adanya orang yang berwakaf (wakif) sebagai subjek wakaf;

2) Adanya benda yang diwakafkan (mauquf);

3) Adanya penerima wakaf (sebagai subyek wakaf) (nadzir); 
4) Adanya 'aqad atau lafadz atau pernyataan penyerahan wakaf dari tangan wakif kepada orang atau tempat berwakaf (simauqufalaihi).

Dalam UU No. 41/2004 tentang Perwakafan (Pasal 6), selain empat unsur di atas dimasukkan juga sebagai rukun wakaf: peruntukan harta benda wakaf dan jangka waktu wakaf. Pengaturan unsur-unsur dalam ketentuan Pasal 217 angka 2 Kompilasi Hukum Islam menyatakan bahwa yang menjadi subyek wakaf atau yang dinamakan dengan wakif itu bisa : orang, orang-orang, badan hukum. Menurut KHI Pasal 215 ayat (2) dan 217 ayat (1) Wakif ialah orang, atau badan hukum yang mewakafkan benda miliknya. Adapun organisasi dan badan hukum diwakili oleh pengurusnya yang sah menurut hukum dan memenuhi ketentuan organisasi atau badan hukum untuk mewakafkan harta benda miliknya sesuai dengan ketentuan anggaran dasarnya.

Sedangkan menurut pasa 215 ayat (4) KHI bahwa benda wakaf adalah segala benda baik yang bergerak atau tidak bergerak. Benda ini disyaratkan memiliki daya tahan dan tidak habis hanya sekali pakai dan bernilai menurut ajaran Islam. Selain itu dalam Pasal 217 ayat (3) benda milik pelaku wakaf, bebas dari segala pembebanan, ikatan, sitaan, dan sengketa. Dalam madzhab Hanafi benda wakaf juga dapat berupa uang, yaitu dinar dan dirham. Disini jelas bahwa uang dapat ditahan pokoknya dan diambil hasilnya, seperti uang yang ditempatkan dalam deposito mudharabah, misalnya; menghasilkan keuntungan yang dapat di manfaatkan tanpa menghabiskan pokoknya, sesuai dengan konsep wakaf berupa menahan pokok dan mengambil manfaat (Anwar: 2007).

Ikrar (pernyataan) wakaf adalah pernyataan kehendak untuk melakukan wakaf, dan harus dilakukan secara lisan dan/atau tulisan oleh wakif secara jelas dan tegas kepada nazir dihadapan Pejabat Pembuat Akta Ikrar Wakaf (PPAIW) dengan disaksikan 2 orang saksi. PPAIW kemudian menuangkannya dalam bentuk ikrar wakaf. Selanjutnya adalah nazir, hal ini dapat terdiri dari perorangan, organisasi atau badan hukum. Apabila perorangan, nazir harus memenuhi syaratsyarat, berupa dewasa, sehat akal dan cakap bertindak hukum (Anwar: 2007). 
Selain itu, dalam UU No. 41/2004 Pasal 10 disyaratkan juga warga negara Indonesia, amanah, beragama Islam. Untuk nazir berupa organisasi disyaratkan bahwa pengurusnya memenuhi syarat nazir perorangan dan organisasi itu bergerak di bidang sosial. Nazir badan hukum selain memenuhi dua syarat organisasi di atas, juga harus memenuhi syarat bahwa badan hukum itu merupakan badan hukum Indonesia dan dibentuk berdasarkan peraturan yang berlaku di Indonesia. Adapun tugas nazir dalam UU No. 41/2004 Pasal 11 dinyatakan bahwa nazir berkewajiban untuk melakukan pengadministrasian harta benda wakaf, mengelola dan mengembangkannya sesuai dengan tujuan, fungsi dan peruntukannya, mengawasi dan melindunginya, serta melaporkan pelaksanaan tugasnya kepada Badan Wakaf Indonesia.

Adapun Syarat-syaratnya sebagai wakif sebagaimana diatur dalam ketentuan Pasal 217 ayat (1) dan ayat (2) Kompilasi Hukum Islam, yaitu:

1) Apabila yang menjadi wakif itu orang atau orang-orang, dipersyaratkan:
a) telah dewasa,
b) sehat akalnya,
c) oleh hukum tidak terhalang untuk melakukan perbuatan hukum, dan
d) dilakukan atas kehendak sendiri.

2) Apabila yang menjadi wakif itu badan-badan hukum Indonesia, maka yang bertindak untuk dan atas namanya adalah pengurusnya yang sah menurut hukum.

Mengenai benda yang di wakafkan bukan benda sembarangan, melainkan benda milik, yang bebas dari segala: pembebanan, ikatan dan sengketa. Syaratsyarat shigah berkaitan dengan ikrar wakaf, yaitu harus memuat nama dan identitas wakif, nama dan identitas nazhir, keterangan harta benda wakaf, dan peruntukan harta benda wakaf, serta jangka waktu wakaf. Untuk mengelola benda wakaf tersebut, maka diadakan nadzir, yang menurut ketentuan dalam Pasal 215 angka 5 Kompilasi Hukum Islam, harus berbentuk kelompok orang atau badan hukum yang diserahi tugas pemeliharaan dan pengurusan benda wakaf. 


\section{PENGERTIAN FINTECH SYARIAH}

Menurut National Digital Research Centre (NDRC), Financial Technology adalah istilah yang biasa digunakan untuk menyebut suatu inovasi di bidang jasa finansial. FinTech sendiri berasal dari kata financial dan technology yang mengacu pada inovasi finansial dengan sentuhan teknologi modern. Konsep financial technology mengadaptasi perkembangan teknologi yang dipadukan dengan bidang finansial pada lembaga keuangan perbankan, sehingga diharapkan dapat memfasilitasi proses transaksi keuangan yang lebih praktis, aman, serta modern. Layanan keuangan berbasis digital yang saat ini telah berkembang di Indonesia, yaitu payment channel system, digital banking, online digital insurance, Peer to Peer (P2P) Lending, serta crowdfunding (Siregar 2016).

Pengertian Fintech Syariah menurut Mukhlisin adalah kombinasi, inovasi yang ada dalam bidang keuangan dan teknologi yang memudahkan proses transaksi dan investasi berdasarkan nilainilai syariah. la berpendapat, walaupun fintech ini merupakan terobosan baru tetapi mengalami perkembangan yang pesat. Islam merupakan agama yang komprehensif sehingga dalam bidang keuangan ini harus memiliki aturan yang sesuai dengan prinsipnya sesuai syariah (Yarli, 2019).

Fintech telah membantu bank syariah dalam kecepatan dan akurasi dalam memproses data operasi bisnis dan pemasaran produk. Penerapan sistem informasi sangat berpengaruh pada industri perbankan, di mana penerapan sistem informasi pada industri perbankan mempunyai dampak yang luar biasa mengingat industri perbankan merupakan salah satu industri yang paling tinggi tingkat ketergantungannya pada aktivitas-aktivitas pengumpulan, pemprosesan, analisa dan penyampaian laporan(informasi) yang diperlukan untuk memenuhi kebutuhan para nasabahnya (Supriadi, 2015). 


\section{PEMBAHASAN}

Teknologi finansial (financial Technology, FinTech) menurut Peraturan Bank Indonesia nomor 19/12/PBI/2017 tentang Penyelenggaraan Teknologi Finansial dapat menyelenggaraan aktivitas keuangan yang berupa; sistem pembayaran, pendukung pasar, manajemen Investasi dan Manajemen resiko, pinjaman, pembiayaan dan penyediaan modal dan jasa finansial lainnya.

Adapun tantangan pasar FinTech Syariah menurut Telkom Indonesia (2017) dalam (Ryandono, 2018) adalah:

1. Kesadaran dan pengetahuan masyarakat tentang keuangan syariah, khususnya FinTech Syariah yang masih kurang;

2. Pertumbuhan ekonomi syariah lambat dan pangsa pasarnya masih kecil;

3. SDM berkualitas di bidang ekonomi syariah masih kurang;

4. Sinergi antara sesama lembaga keuangan syariah dengan lembagalembaga sosial yang bergerak di bidang ekonomi umat, seperti dengan lembaga zakat dan wakaf masih lemah.

Manfaat dari penggunaan kemajuan tekhnologi khususnya berbasis internet dalam bidang findrising wakaf merupakan sebuah peluang yang baik. Selain financial technologi yang bersifat umum, wakaf dapat menjadikan financial technologi syariah sebagai sarana dalam mengumpulkan asset wakaf khususnya uang dari masyarakat yang hari ini semakin sering menggunakan gadget. Manfaat dari penggunaan financial technologi syariah untuk findrising wakaf diantaranya:

1. Sosialisasi dan mobilisasi aset wakaf berupa uang dapat lebih mudah didapatkan dari masyarakat.

2. kemudahan dalam melakukan transaksi wakaf, dari pihak wakif, nadzhir maupun dapat melibatkan aspek perbankan syariah sebagai LKS-PWU sebagai lembaga intermediasi.

3. tidak terbatas ruang dan waktu dalam bertransaksi wakaf. 
4. wakaf dapat dilakukan dari nominal terkecil, sehingga wakif tidak sungkan dalam menyalurkan dana wakaf walau sedikit.

5. transparansi pendapatan asset wakaf yang dihimpun dan akuntabilitas penyalurannya dapat dilihat secara berkala melalui layar smartphone.

Dasar hukum dari financial technologi di Indonesia diantaranya berlandaskan Peraturan Otoritas Jasa Keuangan (POJK) 77 Tahun 2016 tentang Layanan Pinjam Meminjam Uang Berbasis Teknologi Informasi. Aturan tersebut mengatur secara umum setiap jenis fintech P2P seperti fintech syariah dan konvensional. Sedangkan, landasan hukum lain yang lebih khusus terkait fintech syariah mengacu pada Fatwa Dewan Syariah Nasional Majelis Ulama Indonesia (DSN MUI) Nomor 117/2018 tentang Layanan Pembiayaan Berbasis Teknologi Informasi Berdasarkan Prinsip Syariah.

Dalam Fatwanya menurut DSN MUI (2018) terdapat enam jenis akad yang diperbolehkan dalam fintech syariah.

1. al-bai'(jual-beli) yaitu akad antara penjual dan pembeli yang mengakibatkan berpindahnya kepemilikan obyek yang dipertukarkan (barang dan harga).

2. ijarah yaitu akad pemindahan hak guna (manfaat) atas suatu barang atau jasa dalam waktu tertentu dengan pembayaran ujrah atau upah.

3. mudharabah yaitu akad kerja sama suatu usaha antara pemilik modal (shahibu al-maaf yang menyediakan seluruh modal dengan pengelola ('amil/mudharib) dan keuntungan usaha dibagi di antara mereka sesuai nisbah yang disepakati dalam akad, sedangkan kerugian ditanggung oleh pemilik modal.

4. musyarakah yaitu akad kerja sama antara dua pihak atau lebih untuk suatu usaha tertentu di mana setiap pihak memberikan kontribusi danalmodal usaha ( $r a$ 's al-maf dengan ketentuan bahwa keuntungan dibagi sesuai nisbah yang disepakati atau secara proporsional, sedangkan kerugian ditanggung oleh para pihak secara proporsional. 
5. wakalah bi al ujrah yaitu akad pelimpahan kuasa untuk melakukan perbuatan hukum tertentuyang disertai dengan imbalan berupa ujrah (upah).

6. qardh yaitu akad pinjaman dari pemberi pinjaman dengan ketentuan bahwa penerima pinjaman wajib mengembalikan uang yang diterimanya sesuai dengan waktu dan cara yang disepakati.

Wakaf tunai dalam istilah undang-undang wakaf adalah wakaf uang, yaitu memiliki fleksibilitas dalam pengembangannya. Dalam UU wakaf No.41 Tahun 2004 disebutkan bahwa wakaf uang harus melalui LKS-PWU (lembaga keuangan syariah penerima wakaf uang) yang resmi ditunjuk oleh kementrian agama. Sedangkan, istilah wakaf melalui uang sering digunakan dalam hal penggalangan wakaf uang tanpa melalui LKS-PWU dalam hal ini adalah lembaga pengelola wakaf (nadzhir) langsung mendapatkannya dari masyarakat selaku wakif. Adapun Dasar Hukum yang digunakan untuk Wakaf Uang adalah sebagai berikut:

1. UU No. 41 Tahun 2004 Tentang Wakaf

2. PP No. 42 Tahun 2006 Tentang Pelaksanaan UU No. 41 Tahun 2004 tentang wakaf

3. Peraturan Menteri Agama No. 4 Tahun 2009 tentang Administrasi Pendaftaran wakaf uang.

4. Peraturan Badan Wakaf Indonesia No. 1 Tahun 2009 tentang Pedoman Pengelolaan dan Pengembangan Harta Benda Wakaf Bergerak Berupa Uang.

5. Peraturan BWI No. 2 tahun 2010 tentang Tata cara Pendaftaran Nazhir wakaf uang.

6. Peratuarn BWI No. 2 tahun 2009 tentang Pedoman Penerimaan Wakaf uang bagi Nazhir BWI

Dalam penggalangan asset wakaf berupa uang melalui financial technologi syariah ini baik melalui channel perbankan syariah maupun lembaga pengelola wakaf harus mengedepankan aspek transparansi, akuntabilitas, keadilan dan yang 
terpenting sesuai dengan syariat. Inti dari wakaf itu sendiri merupakan bagian dari instrument filantropi Islam yang tetap harus sesuai dengan ketentuan hukum wakaf, yaitu:

$$
\text { (أحبس أصلها وسبل ثمرتها (رواه النسائي) }
$$

"Tahanlah pokoknya dan sedekahkan hasilnya pada sabilillah. " (Hr. AnNasai).

Adapun aspek financial technologi merupakan inovasi yang dibuat dalam memudahkan penghimpunan asset wakaf itu sendiri. Terkait kemajuan technologi tersebut erat kaitannya dengan aspek muamalah sebagai mana kaidah:

$$
\text { الأصل في المعاملة الإباحة حتى يدل الدليل على خلافه }
$$

"Asal pada urusan muamalah adalah boleh sampai ada dalil yang menyelisihinya" (Khalaf: 1375).

Selain itu dalam hadis nabi Muhammad saw:

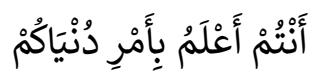

"Kamu lebih mengetahui urusan duniamu" (HR. Muslim, no. 2363).

Sedangkan terkait akad wakaf dalam perspektif Kompilasi Hukum Islam harus memenuhi 4 unsur (rukun), yaitu :

1. Adanya orang yang berwakaf (wakif) sebagai subjek wakaf;

2. Adanya benda yang diwakafkan (mauquf);

3. Adanya penerima wakaf (sebagai objek wakaf);

4. Adanya 'aqad atau lafadz atau pernyataan penyerahan wakaf dari tangan wakif kepada orang atau tempat berwakaf (simauqufalaihi).

Dalam UU No. 41/2004 tentang Perwakafan (Pasal 6), selain empat unsur di atas dimasukkan juga sebagai rukun wakaf: peruntukan harta benda wakaf dan jangka waktu wakaf. Dari unsur rukun dan syarat wakaf dalam fikih wakaf tidak jauh berbeda yaitu harus adanya wakif, mauquf, mawquf alaih dan ijab. Dalam akad wakaf tidak mensyaratkan adanya qabul (AAOIFI, 2017), sehingga jika seorang wakif melakukan ikrar wakaf tanpa diikuti qabul dari pihak kedua secara aturan telah sah, akan tetapi dalam UU No.41 Tahun 2004 mencantumkan 
pentingnya peran nadzhir sebagai pengelola asset wakaf demi kemaslahatan asset tersebut dan ummat, maka dalam UU wakaf tersebut memberikan hak kepada pengelola wakaf dalam hal ini adalah nadzhir 10 persen dalam pengelolaan asset wakaf tersebut.

Sehingga penggunaan fasilitas financial technologi syariah dalam menggalang dana atau asset wakaf berupa uang dari masyarakat tidak menyalahi dari sisi hukum positif maupun hukum Islam. Maka selayaknya segala upaya yang baik dalam mensukseskan dan mengoptimalkan fundrising wakaf uang ini harus didukung oleh semua pihak dalam rangka menghadirkan kemaslahatan yang lebih besar untuk mesyarakat dan negara.

\section{SIMPULAN}

Financial technologi syariah merupakan bagian dari inovasi teknologi yang seharusnya digunakan dengan sebaik mungkin, khususnya dalam kebaikan. Wakaf uang merupakan bagian dari nilai kebaikan Islam yang harus tetap dijaga keasliannya, namun terus dikembangkan manfaatnya. Pengembangan wakaf tidak terlepas dari penggalangan asset wakaf khususnya berupa uang dimasyarkat Indonesia yang kini semakin tinggi angka pengguna gadgetnya. Kemudahan penggunaan fintech syariah dalam menggalang wakaf uang secara hukum positif telah memiliki landasannya secara umum, sedangkan menurut hukum Islam tidak menjadi halangan dalam menggalang asset wakaf uang yang lebih besar lagi dari masyarakat selama tidak melanggar ketentuan syariat.

\section{DAFTAR PUSTAKA}

Al-Mishri, Muhammad Ibn Bakar Ibn Mandzur. 1301. Lisan Al-'Arab, Bulaq: Almishriyah.

Al-Usman, Muhammad bin Shalih. 2008. Panduan Wakaf, Hibah, dan Wasiat Menurut alQur"an dan as-Sunnah, Jakarta:Pustaka Imam Syafi'l.

Anas, Malik bin. 1994. al-Mudawwanah al-Kubra, Beirut: Dar al-Kutub Al-'Ilmiyah. 
Ali al-Nasa'l, Abu Abdu Ar-Rahman Ahmad bin Shu'ayb bin. 1995. Sunan AnNasa'l, Beirut: Dar Al-Fikr.

AAOIFI. 2017. Al-Ma'ayir Asy-Syar'iyyah. Bahrain: Darul Maiman.

Al-Ramli, Shans al-Din Muhammad Ibn Abu Al-Abbas Ibn Hamzah Ibn Shihab alDin. 1984. NIhayah al-Muhtaj ila sharh al-minhaj, Bairut: Dar Al-Fikr.

Anwar, Syamsul. 2007. Studi Hukum Islam Kontemporer, Jakarta: RM Books.

Bakar, Abu et.al. 2006. Filantropi Islam \& Keadilan Sosial: studi tentang potensi, tradisi, dan pemanfaatan filantropi Islam di Indonesia, Jakarta: CSRC UIN Jakarta.

Hanbal, Ahmad Ibn. 2008. Musnad al-Imam Ahmad Ibn Hanbal, Bairut: Dar alKutub al-Ilmiyah.

Khalaf, Abdul Wahab. 1375. 'Ilmu Ushul Fiqh. Mesir: Maktabah Da'wah- Syababul Azhar.

Kompilasi Hukum Islam

Muslim, t.t. Shahih Muslim, Mesir: Dar al-Fikr al-Mu'ashir.

Syarjaya, Syibli and Fahruroji. 2017.Wakaf Uang dalam Perspektif Hukum Islam dan Peraturan Perundang-undangan. Jakarta: CIMB Niaga Syariah.

Zahrah, Abu. 1971. Muhadharat Fi Al-Waqf, Beirut: Dar Al-Fikr Al-'Arabi.

Zuhayli, Wahbah. 1985. al-fiqh al-islami wa adilatuh, Damaskus: Dar Al-Fikr.

Fkr al-Mu'asir.

Muchlis, Ridwan. 2018. Analisis SWOT Financial Technology (Fintech) Pembiayaan Perbankan Syariah Bank Syariah Di Kota Medan, Jurnal At-Tawassuth 3 (2): 335-357.

PP No.42 Tahun 2006 tentang Wakaf

Ryandono, Muhammad Nafik Hadi. 2018. Fintech Waqaf: solusi permodalan perusahaan startup wirausaha muda. Jurnal Studi Pemuda 7 (2):111-121.

Supriyadi, Kurnia and Masjono. 2015. Pengaruh hubungan pemanfaatan aplikasi core banking system terhadap kinerja individu karyawan PT. Bank BRI 
Syariah. Jurnal Akuntansi, Keuangan dan Perbankan (Account) 1 (3): 247254.

UU No. 41 Tahun 2004 Tentang Wakaf

Yarli, Dodi. 2018. Analisis Akad Tijarah Pada Transaksi Fintech. Jurnal Yudisia 9 (2): 245-258. 